\title{
The Effect of Self Coastal Cards on Adherence to Iron Tablet Consumption, Hemoglobin Level, Weight of A Baby, Among Anemia in Pregnancy
}

\author{
Lina Sundayani, Baiq Iin Rumintang
}

\begin{abstract}
The purpose of this research to analize the effect of coastal cards on adherencetoiron tablet consumption, hemoglobin level, weight of a baby, among anemia in pregnancy. This research used quasi experimentalwith design pre and post-test design, which was performed on pregnant women with mild and moderate iron deficiency anemia in the Mataram Health Center. The research subjects consisted of 30 of third trimester of pregnant women who had mild and moderate anemia. Data analysis with Anova one way. The results showed: The level of adherence of 30 study subjects were mostly adherent to taking Iron tablet 29 people $(96.7 \%)$ and only 1 person who was not compliant $(3.3 \%)$. Hb levels in pregnant women at the first day of iron tablet an average of $9.90 \mathrm{gr} \%$, after 2 weeks given an average iron tablet of $\mathbf{1 0 . 8 7}$ gr\%, and before giving birth after being given iron tablet on average $11.84 \mathrm{gr} \%$. Hb levels after childbirth is given an average iron tablet of $11.38 \mathrm{gr} \%$. The weight of babies born is between 2768 grams to 3407 grams and the average baby's weight is 3087.5 grams. experienced Postpartum bleeding, namely 29 people $(96.7 \%)$ and only 1 person $(3.3 \%)$ who experienced postpartum bleeding.
\end{abstract}

Index Terms — coastal cards; adeherence; iron tablet.

\section{INTRODUCTION}

According to WHO (World Health Organization) in 19932005 reported that the prevalence of anemia worldwide occurred in pregnant women, $41.8 \%$, and non-pregnant women $30.2 \%$. Pregnant women are one of the groups prone to malnutrition, due to an increase in nutritional needs to meet the needs of the mother and the fetus it contains. Anemia in pregnancy can have an impact on the occurrence of fetal growth restriction so that the baby is born with a low birth weight (LBW), premature, bleeding during labor, and can continue after delivery, which can cause the death of the mother and baby.

To Accelerate Nutrition Improvement in the Framework of the First 1000 Days of Life (Movement of the First 1000 Days of Life and abbreviated 1000 HPK Movement). SUN (Scaling Up Nutrition) Movement is a global effort from various countries in order to strengthen commitments and action plans to accelerate nutrition improvement, especially nutrition management, for 1,000 days from pregnancy to 2year-old children. So pregnant women as a group in 1000 days need attention [1].

Published on August 10, 2020.

Lina Sundayani, Poltekkes Kemenkes Mataram, Indonesia.

(corresponding e-mail: linasundayani17@gmail.com)

Baiq Iin Rumintang, Poltekkes Kemenkes Mataram, Indonesia.

S. B. Author, Rice University, USA.
In Indonesia, in 2013, anemia in pregnant women amounted to $37.1 \%$, anemia cases in pregnant women were evenly distributed in urban areas, $36.4 \%$, and rural areas $37.8 \%$ (Riskesdas 2013). The results of the 2013 micronutrient evaluation of NTB province showed that of 3000 respondents, $56.5 \%$ had iron deficiency anemia, with the highest distribution (85\%) in Mataram City, and 54\% were the third-trimester pregnant women, this figure was the highest among ten districts in NTB [2].

Especially the consumption of animal food in Indonesian society is still less affordable because the price is relatively high even though animal foods contain iron more easily absorbed. Alternative iron is vegetable food in the form of green vegetables that are more difficult for the body to absorb. Several factors facilitate and inhibit the absorption of iron in the body [3].

Consumption of fruits that contain vitamin $\mathrm{C}$ is very instrumental in the absorption of iron by increasing the absorption of non-heme iron up to four times. This absorption mechanism includes reducing the ferric to ferrous form in the stomach that is easily absorbed. While the inhibiting factors are tannin in tea, phytate, phosphate, and fiber in food, with a low level of protein and iron hem consumption [3], [4].

The body's ability to make red blood cells will inhibit even though animal protein such as meat, fish, and chicken if present in the diet even in small amounts will increase iron absorption because it has high bioavailability, so also with the role of vitamin C [3].

One of the programs implemented by the government to tackle nutritional anemia is the administration of iron tablets as an iron supplement for pregnant women. Blood supplementation tablets (Tablet Tambah Darah/TTD) are needed to prevent and treat iron-deficiency anemia. During pregnancy, the government distributed as much as 90 TTD to each pregnant woman, iron tablet gets starting in the first trimester of pregnancy. The behavior that still needs to be improved is the increase in the consumption of iron tablets for pregnant women. Data on the coverage of iron tablets in NTB is already quite high at $92.4 \%$, but compliance with Iron Tablets consumption is still low. Based on the evaluation of micronutrition in West Nusa Tenggara province in 2013, it was found those anemic pregnant women in the city of Mataram. It was not compliant to drink iron tablets with a percentage of $98.6 \%$. Vitamin C, along with protein and iron, are the ingredients of making red blood cells. Efficient and effective absorption of iron is iron in the form of Ferro because it is easily dissolved, for this reason, it is necessary to have acidic acid in the stomach, 
and the compound that can convert ferric to ferrous in the intestine is vitamin C [4].

Vitamin $\mathrm{C}$ is quite high found in sources that are readily available and inexpensive in the form of lime. The evaluation of micronutrients in West Nusa Tenggara province in 2013 also showed that the majority of respondents, $60.2 \%$, did not consume a source of vitamins in the form of vegetables and fruit. Anemic pregnant women in the city of Mataram had consumed side dishes $(58.7 \%)$ and consumed vegetables $(80.7 \%)$. According to Hardinsyah, Supriasa, the causes of low compliance of mothers consuming supplement tablets from pregnant women themselves are forgetfulness and side effects (nausea, vomiting, dizziness), lack of awareness about the importance of supplement tablets and the threat of anemia for pregnant women, fear of babies being born large and not there is specialized counseling from health workers [14].

Compliance of the mother in consuming iron tablets during pregnancy is an essential factor in improving the quality of her pregnancy. Hemoglobin levels will increase by $1 \mathrm{~g} / \mathrm{dl}$ within 1-2 months if pregnant women regularly take iron-added tablets containing $60 \mathrm{mg}$ of iron. Compliance of pregnant women taking supplement tablets is an essential factor in ensuring an increase in hemoglobin levels in pregnant women [6].

Maternal compliance influenced by the level of knowledge, motivation, family role, and behavior of health workers. Lack of knowledge about pregnant women about iron tablets will increase the risk of pregnant women not complying with their therapy. Moreover, coupled with the lack of information provided by officers regarding iron tablets, which is currently mostly only related to doses, the compliance rate is low [7].

So far, there has not been a special Information, education and communication (IEC) media in the form of a flip sheet for anemic pregnant mothers. The provision of IEC is usually made by midwives and nutrition workers verbally. So, the researchers assume that efforts are needed to increase the compliance of iron tablets consumption in the form of IEC Flip Sheet media, and the iron tablets Monitor Card Sticker carries out on pregnant women with their husbands. In this media will be explained about anemia and its effects, the benefits of iron tablets in overcoming anemia experienced by mothers, how to drink iron tablets that can increase its absorption, especially with the source of vitamin $\mathrm{C}$ that is easy.

\section{MATERIAL AND METHOD}

The research method used was quasi-experimental studies with a pretest post design. This study provides treatment to the intervention group through the provision of interventions to Trimester III pregnant women and their husbands. The effect of treatment is seen in the level of compliance with iron tablets consumption after treatment using a sample group that treated (intervention). The treatment is carried out for 14 days (fourteen days), starting from the start of anemia detected in each respondent.

\section{FINDING}

From the results of research on 30 anemia pregnant women, obedience observes for 14 days ( 2 weeks) with the number of iron tablets that should take as many as 28 tablets with a dose of 2 times a day. The results of monitoring show iron tablets compliance as shown in table.

TABLE 1. Compliance Iron Tablets

\begin{tabular}{ccc}
\hline Compliance with iron tablets & $\mathrm{N}$ & Percentage \\
\hline Regular (more than 25 tablets) & 29 & $96,7 \%$ \\
\hline Irregular (less than 25 tablets) & 1 & $3,3 \%$ \\
\hline
\end{tabular}

Based on the results of the One Way Anova test on $\mathrm{Hb}$ levels in pregnant women, there was a significant difference in the mean $\mathrm{Hb}$ levels of the four observation groups, and this is indicated by the $p$-value $=0,000<\propto$. Furthermore, the multiple comparison test with Least Significant Difference (LSD) obtained and displayed in full presents in the table below.

\begin{tabular}{|c|c|c|}
\hline Hb Levels & Deviation Standard & $\mathrm{P}$ value \\
\hline Day 1 & $9.90 \pm 0.73^{\mathrm{a}}$ & $0.000<\infty$ \\
\hline Day 14 & $10.87 \pm 0.95^{\mathrm{b}}$ & \\
\hline Intra Partum & $11.84 \pm 0.76^{\mathrm{c}}$ & \\
\hline Post Partum & $11.38 \pm 0.81^{\mathrm{d}}$ & \\
\hline
\end{tabular}

In this study, 30 subjects of pregnant women observe until delivery, and the weight of their baby is monitoring. The results of observations of the average body weight of infants obtained will explain in the table below.

TABLE 3: deviations standard

\begin{tabular}{cc}
\hline Variable & Deviation Standard \\
\hline Weigth & $3087.5 \pm 319.3$
\end{tabular}

As shown in Table 3, the weight of babies born shows the mean \pm standard deviation is $3087.5 \pm 319.3$ grams. This means that the weight of a baby born is spread between 2768 grams to 3407 grams and the average baby's weight is 3087.5 grams. The subjects of this study were 30 anemia pregnant women who were observed until delivery. Observation results show the amount of bleeding in Table 4 below.

TABLE 4: Postpartum Bleeding

\begin{tabular}{|c|c|c|}
\hline Postpartum Bleeding & $\mathrm{n}=30$ & $\%$ \\
\hline Bleeding $\leq 500 \mathrm{cc}$ & 29 & 96.7 \\
\hline Bleeding $>500 \mathrm{cc}$ & 1 & 3.3 \\
\hline
\end{tabular}

Table 4 shows that the majority of study subjects did not experience bleeding (96.7\%) and only 1 person $(3.3 \%)$ experienced bleeding where the mother delivered by Sectio Caesaria (SC) due to oligohydramnios and a narrow pelvis.

In the previous research, the form that we made was in the form of a Mandiri Monitoring Card. Still, based on the results of evaluation and observation, if it is in the form of a sticker, it can only be posted at home and cannot be taken during pregnancy check-up to be monitored by a midwife. 
This card is made two sides (back and forth) on the back sheet added monitoring by the husband and health workers in the form of initials and re-monitoring of hemoglobin levels, also, given some vital information related to anemia and iron tablets that mothers can read at home.

Health education with the application of appropriate methods of communication of information and knowledge turns out to make pregnant women aware that they have anemia and moved to make improvements in the form of more adherent to taking iron tablets to increase hemoglobin (Hb) levels. An independent monitoring card that gave to pregnant women, written down the name of the pregnant woman and $\mathrm{Hb}$ levels, and then hung by the mother in an easily visible place, admittedly the mother is beneficial to remind mothers to take TTD. Every time you see this later, the mother immediately remembers to drink iron tablets, and this card also helps her husband and other family members who live in the same house with the mother to help remind mothers to drink iron tablets. Consistent with the theory, which states that increasing knowledge of the importance of supplementation can increase the compliance of pregnant women in consuming blood-added pills. Experience is a predisposing factor that influences health behavior, but the motivation to change behavior also plays an important role.

Quality pregnancy examinations also support compliance with iron tablets consumption. Pregnancy examinations carried out by midwives are integrated activities in the form of anemia findings for pregnant women, management, and evaluation of care. This quality must be maintained by referring to the antenatal standard.

The provision of IEC is more focused on information about the definition of anemia, the effects of anemia, and the benefits of iron tablets to overcome anemia. The result of increasing $\mathrm{Hb}$ levels is an indicator for midwives for the quality of antenatal services they do [6].

Factors that cause low compliance of pregnant women taking iron tablets are not feeling sick, ignorance of anemia symptoms, the effects of anemia, little motivation to take iron tablets for a long time, and the side effects of taking iron tablets [8].

The application of $10 \mathrm{~T}$ antenatal care standards, an atmosphere of openness in service, effective IEC methods, independent monitoring cards, and the participation of husbands/family members to help remind pregnant women to play a significant role in improving iron tablets compliance. So, the results of this study indicate that the effort to modify an independent monitor card in anemic pregnant women is very vital in increasing the compliance of weak pregnant women in consuming iron tablets [8].

\section{CONCLUSION}

From 30 study subjects, 29 people adhered to taking iron tablets $(96.7 \%)$ while only 1 person did not (3.3\%). Hemoglobin levels in Pregnant Women with Anemia after the first day of iron tablets is an average of $9.90 \mathrm{gr} \%$, then Hemoglobin levels in Pregnant Women with Anemia after 2 weeks given iron tablets is an average of $10.87 \mathrm{gr} \%$. Hemoglobin levels in Pregnant Women with Anemia before giving birth after being given iron tablets is an average of 11.84 gr\% then Hemoglobin levels in Pregnant Women with
Anemia after giving birth iron tablets is an average of $11.38 \mathrm{gr} \%$. There were significant differences in hemoglobin levels from the four observation stages. The weight of babies born is between 2768 grams to 3407 grams and the average baby's weight is 3087.5 grams. Of the 30 study subjects, 29 people did not experience bleeding $(96.7 \%)$ and only 1 person $(3.3 \%)$ experienced postpartum bleeding.

\section{CONFLICT OF INTEREST}

There is no conflict interest in this research

\section{SOURCE IF FUNDING}

This research funding by Ministry of health of Indonesia

\section{ETHICAL Clearance}

Ethical approvalforthis studywas obtained from University of Mataram number: 121/UN18.8/ETIK/2017.

\section{REFERENCES}

[1] Aditiani, Yurista P, Elisa Diana. 2015.

[2] Pendampingan minum Tablet Tambah Darah (TTD) dapat meningkatkan kepatuhan konsumsi TTD pada ibu hamil anemia.Jurnal Penelitian Gizi dan Makanan. Vol.38((1):71-78.

[3] Arikunto S.2006. Prosedur Penetian Suatu Pendekatan Praktik. Jakarta: Rineka Cipta.

[4] Balarajan, Ramakrishnan U, Ozaltin E, Shankar AH, Subramanian SV. Anemia in Low-Income and Middle Income Countries. Lancet. 2011; 378(12):2123.

[5] Dinas Kesehatan Provinsi NTB. 2013. Evaluasi gizi mikro provinsi NTB. Mataram. Dikes Provinsi NTB.

[6] Direktorat Jenderal Kesehatan Ibu dan Anak. 2010. Pedoman Pelayanan Antenatal Terpadu. Jakarta.

[7] Eva R. 2009. Hubungan Karakteristik Pengetahuan dan Sikap Ibu Hamil dengan Pemeriksaan.

[8] Haemoglobin Sewaktu Hamil di Puskesmas Darussalam Kecamatan Medan Petisah. Medan.

[9] Fakultas Kesehatan Masyarakat Universitas Sumatra Utara. Didapat dari:repository.usu.ac.id/bitstream/123456789/14742/1/09E00548.pdf

[10] Kementerian Perencanaan Pembangunan Nasional. 2010.Peta Jalan Percepatan Pencapaian Tujuan Pembangunan Milenium di Indonesia. Jakarta: Badan Perencanaan Pembangunan Nasional (BAPPENAS).

[11] Kemenkes RI. 2015. Pedoman Penatalaksanaan Pemberian Tablet Tambah Darah. Jakarta: Direktorat.

[12] Jenderal Bina Gizi dan Kesehatan Ibu dan Anak.

[13] Kemenkes RI.2013. Riset Kesehatan Dasar 2013. Jakarta: Kementrian Kesehatan RI.

[14] Hardinsyah, Supriasa I DN. 2017. Ilmu Gizi Teori dan Aplikasi. EGC. Jakarta.

[15] Mubarak, Wahit I. 2007. Promosi Kesehatan Sebuah Pengantar Proses Belajar Mengajar Dalam Pendidikan. Graha Ilmu.

[16] Notoatmojo,S. 2010. Metodelogi Penelitian Kesehatan. Jakarta: Asdi Mahasatya.

[17] Sam Ononge, Oona Campbell, Florence Mirembe.2014. Hemoglobin status and Predictor of Anemia among Pregnant Women in Mpigi Uganda. BioMed Central. 